\title{
How do flow experiences and emotional states of individuals participating in recreational activities affect their self-efficacy perceptions and life satisfaction?"
}

\author{
Gamze Eryılmaz*, Kamil Unur, Yılmaz Akgündüz
}

\section{ABSTRACT}

Keywords:

Flow Experience,

Positive Emotions,

Negative Emotions,

Self-Efficacy,

Life Satisfaction

Article History:

Submitted: 08.01.2021

Accepted: 14.06.2021
This research is based on social cognitive theory and aims to determine the effects of flow experience and positive and negative emotional states of individuals participating in recreational activities on their selfefficacy. The study also aimed to explore the effect of flow experience, self-efficacy, and positive-negative emotions on individuals' life satisfaction. The data were collected through a valid and reliable scale. Convenient sampling method was employed and 434 valid questionnaires were collected between January and April 2018. Hypotheses were tested by multiple regression analysis. Results show the balance between challenges and skills subscale of flow experience and positive emotional state affect selfefficacy. In addition, life satisfaction is affected by flow experience, positive emotions and self-efficacy. Based on the relevant findings and inferences, some suggestions have been developed for the enterprise or operators. Within the scope of the flow experience, balance between challenges and skills can be taken into account by the companies that work with intensive business timetable (for example: businesses where the service is offered on site, such as hotels, restaurants). A further suggestion can be made for managers of sports clubs, fitness center operators, course managers (such as swimming, dancing) and public managers. More individuals should be directed to do physical activities for themselves, regardless of whether they are indoor or outdoor activity.

\section{Doi: https://doi.org/10.31822/jomat.2021-6-2-127}

\section{Introduction}

The flow means that individuals get so much into an activity or event and this experience can be enjoyable to the extent that individuals need to pay a price for it (Csikszentmihalyi, 2005, p. 6). Flow examines the process of achieving happiness by controlling the inner life of the individual (Csikszentmihalyi, 1990). The Flow Theory, developed by Csikszentmihalyi, explains why people do something for themselves and participate in activities (Csikszentmihalyi \& LeFevre, 1989, p. 816).

Subjective well-being in flow theory means that individual engages with activities that correspond to one's skills. In other words, it is accepted as the state of regularity in the consciousness formed by the sum of the flow experiences while struggling with difficulties (Csikszentmihalyi, 1990). The genetic characteristics of the individuals and the environment in which they live cause themselves to experience flow. The individual who experienced flow is happy because of developing and realizing oneself (Csikszentmihalyi \& LeFevre, 1989), which in turn increases quality of life and life satisfaction (Sahranç, 2007).

Social Cognitive Theory defines self-efficacy as the internal belief that the individual can overcome encountered difficulties by self-evaluating the circumstances (Bandura, 1986). Experiences, the achievement of other individuals with whom one compares him/herself, the opinions of others about the one's competence and the physical and emotional state affect self-efficacy belief. The positive emotions increase his self-efficacy whereas negative emotions cause a decrease (Gupta \& Kumar, 2010).

In the literature, there are studies examining the relationship between flow experience and self-

\footnotetext{
*Corresponding Author

Gamze Eryulmaz: Asst. Prof. Dr., Iskenderun Technical University / Hatay, Turkey, Email: gamze.eryilmaz@iste.edu.tr, Orcid Id: 0000 0003-0588-8021

Kamil Unur: Prof. Dr., Mersin University, İskenderun / Hatay, Turkey, Email: kunur@mersin.edu.tr, Orcid Id: 0000-0003-2992-7427 iD
}

Yılmaz, Akgündüz: Assoc. Prof. Dr., Dokuz Eylul University, Mersin, Turkey, Email: yilmazakgunduz@hotmail.com, Orcid Id: 0000-00018887-9280 
efficacy (Basom \& Frase, 2004; Frase, 1998; Hong et al., 2012; Mesurado, Cristina Richaud, \& José Mateo, 2016; Reid, 2004; Sahranç, 2008). However, it has been observed that there is no study that directly examines this relationship in the recreation and tourism literature. Considering the relationship between flow experience and satisfaction with life, it can be mentioned that there are a limited number of studies in the field of recreation, tourism and sports (Sidorová, 2015; Baek, 2017; Ayazlar \& Yüksel, 2018). Although limited, in parallel with the relational situations mentioned, in the case of individuals participating in recreational activities; how flow experience and emotional states affect self-efficacy and life satisfaction is the main problem of this study. This problem determines the purpose of the research. The main purpose of this study is to determine the effect of flow experiences and emotional states (positive-negative) of individuals participating in recreational activities on their self-efficacy and life satisfaction. In addition, the study aimed to determine the effect of self-efficacy on life satisfaction. Self-efficacy plays a key role in behavioural psychology, but there is no research that looks at the flow experience, life satisfaction and emotions. Besides, this research has looked into individuals doing recreative activities, which makes it unique since there is no empirical research in this field.

\section{Literature Review}

\section{Flow Experience}

Flow experience is defined individual participating in an any activity keep the balance between challenges and skill at a high level, have a clearly defined purpose, feel in charge and receive feedback, concentrate on the activity and enjoy it (Csikszentmihalyi, 2005). Moneta (2004) focusses on the individual's compliance with the activity, defines the flow experience as concentration of the individual on the activity, cognitive competence during the activity, the pleasure one gets from the activity and feeling fully compatible with the activity.

Flow experience, in other words, is optimal performance mood and a concept based on flow theory (Aşçı, Çağlar, Eklund, Altıntaş, \& Jackson, 2007). Flow theory aims to understand why people do something for themselves (autotelic) and participate in activities. The theory argues, in the case of mental (psychic) disorganization, or irregularity in consciousness, the individuals may control their inner lives, as this will allow them to direct their attention to a particular purpose and to combat the challenges they come across. Meanwhile, the individual feels the joy and pleasure. This pleasant experience of the individual is accepted as flow experience (Csikszentmihalyi, 2005).

Csikszentmihalyi (1990) talks about many qualities that make activities more enjoyable and create a feeling of inner satisfaction. These qualities are listed as balance between challenges and skills, concentration, clear goals, unambiguous feedback, action-awareness, sense of control, loss of self-consciousness, transformation autotelic experience. If the individual has at least one of these mentioned qualities while performing an activity, then there is flow experience (Aşçı et al., 2007; Aykol \& Aksatan, 2013; Csikszentmihalyi, 1990; Jackson \& Marsh, 1996; Nakamura \& Csikszentmihalyi, 2002).

There are many studies in the literature that looks into the qualities of flow experience and flow experience measurement and they investigate different dimensions and aspects of the experience (Jackson \& Eklund, 2002; Jackson, Martin, \& Eklund, 2008; Magyaródi, Nagy, Soltész, Mózes, \& Oláh, 2013; Rheinberg, Vollmeyer, \& Engeser, 2003; Sahranç, 2008). For example, Magyaródi et al. (2013) evaluated the scale of Flow State Questionnaire (FSQ). The scale has 20 items and has two subscales. These are balance between challenges and skills and absorption in the activity.

Balance between challenges and skills: It expresses the balance between the competencies of the individual and the cahallenges of the activity (Jackson \& Csikszentmihalyi, 1999). At the same time, clear goals (the individual knows what to do during the activity) and the sense of control (the individual feels in charge during the activity) are evaluated within this scope (Magyaródi et al., 2013; Özdemir, Durhan, \& Akgül, 2020; Turan, 2019).

Absorption in the activity: This is about the individual's complete immersion in the transformation of time (the individual loses the perception of the time) (Magyaródi et al., 2013). This subscale evaluates the loss of selfconsciousness, total concentration on the task (the individual does not care what is going on around him and focues only on the goal) (Csikszentmihalyi, 1990) and action-awareness merging (Magyaródi et al., 2013; Özdemir, Durhan, \& Akgül, 2020; Turan, 2019).

\section{Emotional States}

Emotional states are considered under two dimensions as positive and negative emotion. 
Positive emotion (PE) defined as an individual's feeling of enthusiastism, awake and active whereas negative emotion (NE) defined as subjective distress and lack of pleasure in enjoying the life (Watson, Clark, \& Tellegen, 1988). Positive emotion includes pride, satisfaction, happiness, trust, comfort and similar emotional states. Negative emotion expresses a different structure where the individual experiences sadness or fear (Doğan \& Özdevecioğlu, 2009).

While high PE refers to high energy, full focus and enjoyment of life, low PE refers to the situation where enjoyment of life is low, and the individual is more likely to be inactive. High NE expresses a situation where negative moods such as anger, fear and guilt are prevalent; low NE refers to the state of being calmer and quiet (Watson et al., 1988). Experiencing anger, tension, anxiety and guilt is not compatible with the absence of positive emotion. This situation is defined as the lack of negative emotions (Cropanzano, Weiss, Hale \& Reb, 2003; Doğan \& Özdevecioğlu, 2009). Although positive and negative moods seem to be opposite and negatively related, they are theoretically and empirically independent structures. Therefore, it is likely that individuals can experience both emotions simultaneously (Diener \& Emmons, 1984; Warr, Barter, \& Brownbridge, 1983).

\section{Life Satisfaction}

Neugarten, Havighurst and Tobin (1961) are the first one who used the concept of Life Satisfaction. Life satisfaction is defined both cognitively and emotionally. Cognitively, it compares the standards set by the individual with their own conditions. It is expressed as the individual's own assessment, and the criteria deemed appropriate, independent of the standards imposed by external factors (Diener, Emmons, Larsen, \& Griffin, 1985). Emotionally, life satisfaction is defined as the conscious experience of the individual based on positive emotions over negative emotions (Frish, 2006 , p. 21). Since the measurement of cognitive life satisfaction is easier than measurement of emotional life satisfaction and more consistent results can be achieved in terms of validity and reliability, the definition of life satisfaction in a cognitive sense is more prominent in the literature (Diener \& Seligman, 2004; Deniz, 2006).

General life satisfaction, which corresponds to the cognitive evaluation of life satisfaction, is the result of the individual's assessment of life satisfaction as a whole (Sahranç, 2007). Life satisfaction differs from satisfaction in specific living spaces (such as job or marriage satisfaction) in the form of a subjective state of consciousness. Life satisfaction is an assessment of life or life satisfaction as a whole, and it is different from satisfaction with specific living spaces (such as job or marriage satisfaction) as a subjective state of consciousness (Ehrhardt, Saris, \& Veenhoven, 2000).

\section{$\underline{\text { Self-Efficacy }}$}

Although, the concept of self-efficacy is one of the structures of Social Cognitive Theory. The theory is introduced in Bandura's (1986) book of 'Social Foundations of Thout and Action'. Bandura (1986) argues that self-efficacy is one of the concepts that form the core of Social Cognitive Theory. He advocates that Social Cognitive Theory is effective on behaviours. According to the theory, individual evaluates and controls himself/herself before encountering conditions that determine future. The individual is the product and the producer of environment and social systems. Individual's power on the environment and social systems stems from one's belief in own talents (Bandura, 1977; Bandura, 1986). Bandura (1982, p. 123) emphasizes that one's belief in own abilities can be predicted and called as 'self-efficacy'. Bandura (1986, p. 391) defines self-efficacy as a belief in how well an individual can take the necessary actions to manage possible situations. According to Bandura, self-efficacy beliefs affect an individual's feelings, thoughts, motivation and behaviour. Selfefficacy is not a perceived or observed skill, but an internal assessment of what an individual can do with certain skills against certain conditions (Akgündüz, 2013; Bandura, 1994; Keskin, 2020; Kızanlıklı \& Silik, 2019; Maddux, 2002).

\section{Hypothesis of the Research}

Self-efficacy, based on Social Cognitive Theory, affects how the individual behaves, how much effort one takes and how long it lasts (Tipton \& Worthington, 1984). In this context, depending on the flow theory, it can be said that the self-efficacy beliefs they have about the activities they will participate in affect the attitudes of individuals towards these activities.

Individuals' success or failure affects their attitudes towards similar activities they will do in future (Sahranç, 2007). Completing the activity successfully increases the desire to participate in the activity and the level of the effort, depending on the effect of experiences on self-efficacy (Bandura, 1986). Therefore, a successful flow experience increases the individual's self-efficacy belief for both the achieved and similar activities. This also leads to the absorption in the activity. 
The research of Tandon (2017), Mesurado et al. (2016) and Reid (2004) also show the positive effect of flow experience on self-efficacy. $\mathrm{H} 1 \mathrm{a}$ and $\mathrm{H} 1 \mathrm{~b}$ hypotheses have been developed based on relevant explanations, conclusions and studies supporting the relationship between flow experience and selfefficacy.

H1a: The perceptions of individuals participating in recreational activities regarding the balance between challenges of the activity and their skills positively affect their self-efficacy.

H1b: Individuals participating in recreational activities absorption in the activity positively affect their self-efficacy.

According to the activity theory, individuals consider their physical and emotional states while judging their capacities (Certel, Bahadır, Saracaloğlu, \& Varol, 2015, p. 309). Therefore, flow theory can best explain the emotional state (Yetim, 2001). The individual feels delightful if $\mathrm{s} / \mathrm{he}$ believes that $\mathrm{s} / \mathrm{he}$ can overcome the difficulties of the activity with his/her own skills. In other words, if the skill level of the person is sufficient, the flow of activities and the factors that resist these activities will increase the pleasure. If the individual evaluates the activity as very easy, he / she will consider this activity annoying. If the activity is considered to be difficult then this will increase the anxiety (Yetim, 2001, p. 257). Therefore, perception of difficulty or achievability regarding the activity affects the emotional state of the individual (Csikszentmihalyi, 2005).

Bandura (1986) emphasizes that the physical and emotional state of the individual is one of the factors affecting the self-efficacy belief. Therefore, the feelings of anxiety and stress my increase if individuals believe that they cannot successfully complete the activity. When they believe that they can achieve using their skills, then their selfefficacy and positive emotions increase (Bandura, 1986). Therefore, it can be said that the relationship between individuals' positive and negative moods and self-efficacy beliefs begins with the evaluations of individuals about their own skills. The research of Marat (2003), Gupta \& Kumar (2010) and Caprara et al. (2006) show that there is a relationship between positive and negative emotions and self-efficacy. Based on the explanations and studies that are thought to support the relationship between these two concepts, it is predicted that positive emotional state will affect self-efficacy positively, negative emotional state will affect self-efficacy negatively.
H2a and H2b hypotheses have been developed as follows:

H2a: Positive emotional states of individuals participating in recreation activities positively affect their self-efficacy.

H2b: Negative moods of individuals participating in recreation activities negatively affect their selfefficacy.

Life satisfaction is a general assessment of the individual's experience of activities in work and family life (Sahranç, 2007). The individual who is happy with the experience of the activity and who enjoys the experience looks for more experience (Moneta, 2004, p. 115). These experiences also include actions taken in daily life. Depending on the flow experience, the relationship between flow and life satisfaction arises from the activities that the individual performs within the working time and in free time (Larson \& Csikszentmihalyi, 1978). The research of Collins et al. (2009), Han (1988) and Bryce and Haworth (2002) that looks into flow experience and life satisfaction show that the relationship between flow experience and life satisfaction is twofold. Accordingly, the flow experience ensures that the individual is happy. Drawing on the aforementioned research, it has been predicted that the subscales of flow experience will positively affect life satisfaction and $\mathrm{H} 3 \mathrm{a}$ and $\mathrm{H} 3 \mathrm{~b}$ hypotheses have been developed.

H3a: Perceptions of individuals participating in recreational activities regarding the balance between their skills and the challenges of the activity positively affect their life satisfaction.

H3b: Individuals' absorption in the activity positively affects their life satisfaction.

According to the flow theory, which is considered as the determinant of the activity theory, the individual falls into certain emotional states (Csikszentmihalyi, 2005). Since the positive and negative emotions of the individual participating in the activity shape the emotional well-being, the evaluation of this emotional state will have an impact on the life satisfaction of the individual. This situation is explained in the form of life satisfaction as a result of the individual's expectations and the comparison of what one (Çetinkaya, 2011). Therefore, life satisfaction can be examined as an output of the flow experience.

The research of Deniz et al. (2012), Kuppens, Realo and Diener (2008), and Palmer, Donaldson and Stough (2002) suggests that negative emotions reduce life satisfaction, and positive emotions 
increase life satisfaction. Consequently, $\mathrm{H} 4 \mathrm{a}$ and $\mathrm{H} 4 \mathrm{~b}$ hypotheses have been developed since positive and negative emotional states are expected to affect life satisfaction based on these inferences and research.

H4a: Positive emotional states of individuals participating in recreation activities positively affect their satisfaction with life.

$\mathrm{H} 4 \mathrm{~b}$ : Negative emotional states of individuals participating in recreation activities negatively affect their life satisfaction.

Life satisfaction is determined based on the individuals' evaluation of the processes associated with their life patterns and standards (Telef, 2011). Life satisfaction can be expressed as the degree of achieving the goals set by the individual (Aysan \& Bozkurt, 2004). Self-efficacy beliefs positively affect the individual's living conditions as it motivates individuals to achieve their goals regardless of other factors (Bandura et al., 2001). The empirical study of Singh and Udainiya (2009), Azar, Vasudeva and Abdollahi (2006), Verbruggen \& Sels (2010) and Sahan et al. (2012) show that there is a relationship between self-efficacy and life satisfaction. Therefore, as the Social Cognitive Theory suggests, the H5 hypothesis has been developed. It is expected that there will be a relationship between the individual's beliefs about their own competencies, that is, self-efficacy beliefs and life satisfaction.

H5: Self-efficacy of individuals participating in recreation activities positively affects their life satisfaction. Figure 1 presents the model showing the research hypotheses.

\section{Method}

\section{Data Collection}

The research process was carried out in two stages. First, pretest was conducted to test the comprehensibility and reliability of the scale items between October and November, 2017 in Mersin. Data were collected by convenient sampling and through face-to-face interview technique with 67 participants who were active in indoor and outdoor areas. However, the data of 63 participants were taken into consideration when the missing data were removed from the data set. The reliability coefficients $(\alpha>.70)$ for the whole scale and the items representing each structure were highly acceptable (Nunnally, 1978, p. 245).

After the pre-test process in which item reliability was tested, data collection process was performed to test hypothesis. This process was carried out between January and April, 2018 with convenient sampling method. The population of the study includes individuals who participate in activities and who are active in the indoor and outdoor areas. The data were collected from individuals and university students participating in mountaineering, dance, travel and hiking clubs, fitness and bowling halls, playing outdoor and indoor football and basketball, and taking part in walking trails activities in Mersin, Antalya, Adana, Kayseri and Sivas. Mersin Youth Services Sports Provincial Directorate contributed to the data collection process and helped us collect data from their sports units.

\section{Population and Sampling}

At the end of the data collection process, 466 questionnaires were obtained. However, during the

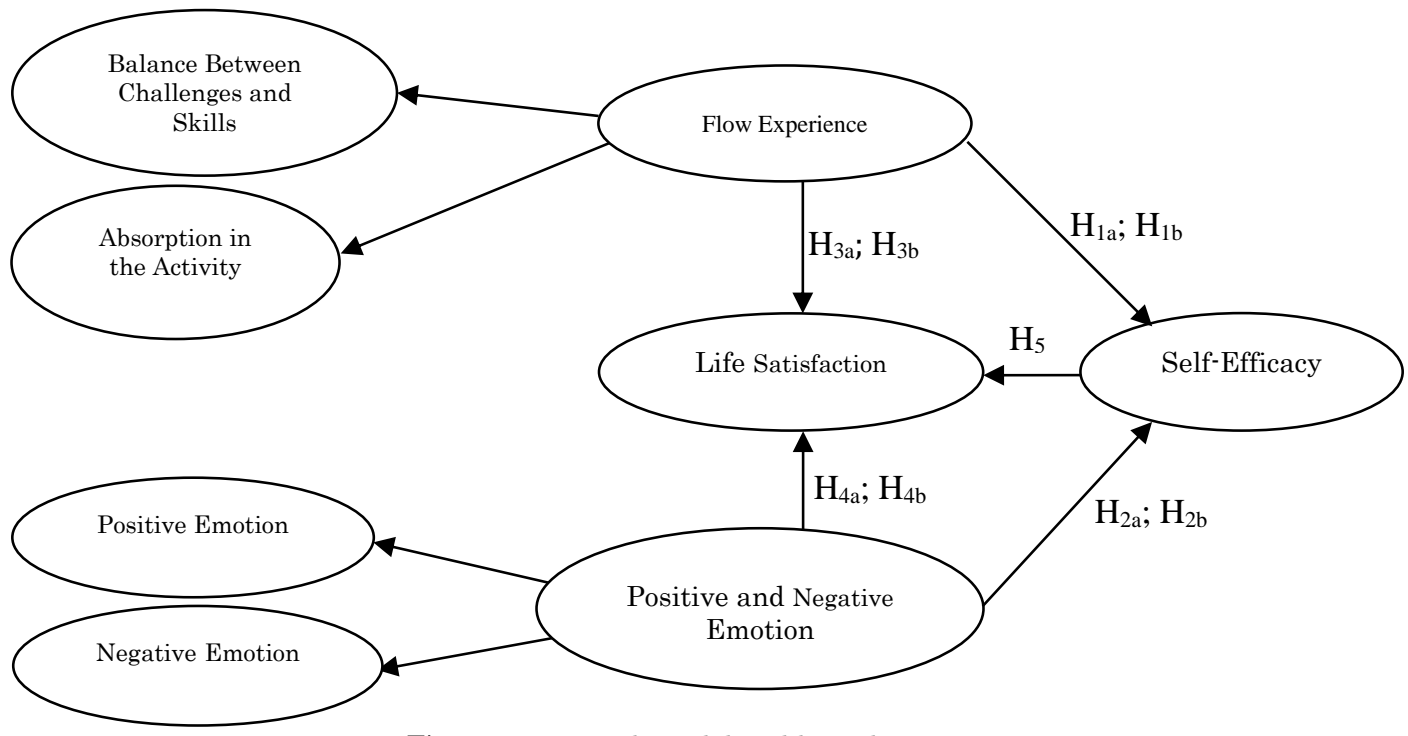

Figure 1: Research model and hypotheses 
preparation of the data for analysis, 31 questionnaires were found to have missing data and 1 questionnaire determined as a sling in multiple normal distribution test, and therefore they were removed from the analysis. In total, 434 questionnaires were used. According to Sekaran (1992), the number of samples for the universe size of 10.000 .000 and above is 384. According to the Turkey Statistical Institute, 2017 Turkey's population is 80.810 .525 (TÜIK, 2018). Thus, the current 434 data reached at the end of the data collection process are thought to represent the population.

\section{Data Collection Tool}

Questionnaire form was used to collect data. The survey form consists of two parts. The first part consists of four scales. Flow State Questionnaire (FSQ) developed by Magyaródi et al. (2013) was used and adapted to Turkish. The FSQ has 20 items and two subscales and aims to measure flow experience. In the adaptation process, we first got expert opinions and then pretested with it with 63 participants for the comprehensibility and reliability of the items. Scale reliability $(\alpha>80)$ was found high. However, statements (Since the data were collected face to face, relevant determinations were made by following the verbal statements of the participants) that were found 2018

to be not understood by the participants during the data collection process were reviewed once again by the same experts at the last stage. Then again data collection has started. From this point of view, it can be said that the content validity for flow experience scale items is met. Content validity is evaluated as referring to "expert opinion" and determining the appropriate one accordingly, regarding situations where the expression structures in the measurement tool are not suitable or appropriate for the purpose of measurement, representing the area to be measured or not (Karasar, 2002, p. 151)

The Positive and Negative Affect Schedule (PANAS) developed Watson et al. (1988) was used to measure emotional states. The sale has 20 items and two subscales. The scale was adapted to Turkish by Gençöz (2000). We used the work of Gençöz to measure positive and negative emotional states.

Generalised Self-Efficacy Scale consisting of 10 items and one subscale was used. The scale was developed by Schwarzer et al. (1997) The translation of the scale from Germen to Turkish was done by Yeşilay, Schwarzer and Jerusalem
(1996). We adapted the statements according to the purpose of this study.

The Satisfaction with life Scale (SWLS) consists of 5 items and one subscale. It was developed by Diener et al. (1985). Köker (1991) and Dağlı and Baysal (2016) carried out the Turkish adaptation of the questionnaire. Based on the relevant studies, we adapted the statements according to the purposes of the research. All scale items are expressed in 5-point Likert type.

The second part of the questionnaire includes demographic statements such as age and the province, gender, marital status, educational status (primary, secondary, high school, associate, undergraduate, graduate), family monthly income (1650 TL and less, 1651 TL -3300 TL, 3301 TL $4950 \mathrm{TL}, 4951 \mathrm{TL}-6600 \mathrm{TL}, 6601 \mathrm{TL}-8250 \mathrm{TL}$, $8251 \mathrm{TL}-9900 \mathrm{TL}, 9901 \mathrm{TL}$ and above), income group (low, middle, middle, middle, high).

In order to follow and observe the variety of activities in the demographic section, the participants were asked most frequently and how often they exercise. At the same time, the type of physical activity (individual (alone), group (made with the team), and the area in which they performed the activity (nature-outdoor, indoorindoor) were asked as closed-ended statements.

\section{Analysis and Findings}

In the analysis process of the research, the aim is to describe the characteristics of the participants, test the validity and reliability, and analyze the relational structures. Then, we tested the hypothesis using regression analysis.

Before proceeding to the analysis, the loss data rate was calculated to be around 10\% (Hair, Black, Babin, \& Anderson, 2010) and no data has been removed from the data set. Then, multiple sling analysis was conducted. As a result of the analysis, only one data was determined as a slingshot and was removed from data set. After multiple sling analysis, multiple normal distribution control was performed and it was determined that the data showed a multivariate normal distribution (correlation coefficient> .962) (Kalayc1, 2010). The data (434 questionnaires) were evaluated and the analysis phase was started. In the analysis process, descriptive analysis related to demographic variables were used to determine the characteristics of the participants. Findings regarding the demographic characteristics of the participants are presented in Table 1. 
Journal of multidisciplinary academic tourism 2021, 6 (2): 127-142

\begin{tabular}{|c|c|c|c|c|c|}
\hline Male & 266 & 61 & Unemployed & 199 & 50 \\
\hline $12-20$ & 95 & 22 & 1650tl and less & 89 & 21 \\
\hline $21-30$ & 244 & 57 & $1651 \mathrm{tl}-3300 \mathrm{tl}$ & 176 & 42 \\
\hline $31-40$ & 70 & 16 & 3301tl-4950tl & 90 & 21 \\
\hline Married & 90 & 24 & 8251 tl-9900tl & 3 & 7 \\
\hline Single & 297 & 76 & 9901tl and above & 4 & 1 \\
\hline Education Status $(\mathrm{n}=428)$ & & & Income Group $(\mathrm{n}=428)$ & & \\
\hline Primary & 5 & 1 & Low & 63 & 14 \\
\hline Secondary & 9 & 2 & Lower-Middle Income & 100 & 23 \\
\hline Activity Type $(\mathrm{n}=432)$ & & & Activity Area (n=434) & & \\
\hline Individual (solo) & 179 & 41 & Outdoor & 200 & 46 \\
\hline Group (with a team) & 253 & 59 & Indoor & 234 & 54 \\
\hline
\end{tabular}

In addition to the demographic information presented in Table 1, the type of physical activity of the participants has also been identified. The most common activities were listed as fitness, hiking, mountaineering, dance, football, basketball, mixed martial sports, bowling, cycling, volleyball, swimming, skiing. The least performed activities are tennis, table tennis, kickboxing, handball, golf, pinball, diving, billiards, paragliding, archery, horse riding and athletics, respectively. Participants stated that they carried exercise "three days a week", "every 15 days", "once a month" or "daily".

Explanatory factor analysis was used for construct validity. The purpose of the explanatory factor analysis (EFA) is to test whether the items represent that structure. In factor analysis, each subscale should consist of at least three factor items, and one item should load only one factor (value).

However, if the items load on more than one factor and extraction values (how much each item affects the total factor) is below 0.40, re-analysis is recommended without including those items in the scale (Büyüköztürk, 2013, p.135; Sipahi, Yurtkoru, \& Çinko, 2010, p. 81). Accordingly, using the principal components method and the Varimax conversion method, factor structures with an eigenvalue above 1 (no load value differences between the items exceeding 0.200 ) were preferred (Büyüköztürk, 2013, p. 135). In the next stage of the analysis process, considering the relevant criteria, factor analysis was performed for each variable separately. The findings are included in Table 2 .
In the first stage, factor analysis related to flow experience with two subscales was carried out (balance between challenges and skills and absorption in the activity). In this process, the analysis took place in two stages. In the first-round analysis, it was determined that the extraction values of the two items were below 0.40 for balance between challenges and skills. (Sipahi et al., 2010, p. 81). This was considered as an appropriate value to exclude these items from the analysis. The second round of analysis was carried out after the two items mentioned were removed. The balance between the challenges and skills of the flow experience scale in EFA was gathered under 10 items and absorption in the activity under 8 items and two factors.

In the second stage, we conducted factor analysis with two subscales positive mood and negative emotions. Each subscale is gathered under its own structure. In the third stage, EFA was applied to the self-efficacy scale consisting of 10 items. The results show that all items were collected under one subscale. In the fourth stage, EFA was applied to the life satisfaction scale and the analysis took place in two stages. In the first round analysis, it was determined that the extraction value of a substance was below 0.40 and therefore an item was removed. In the second round, life satisfaction was evaluated on four items. In the factor analysis process, Kaiser-Meyer-Olkin (KMO), which is a measure of the sampling adequacy of the data structure, and Barlett Sphericity tests, which are used to determine whether the data has a multivariate (interrelated) structure, were conducted (Çokluk, Şekercioğlu, \& Büyüköztürk, 


\section{Jomat}

Table 2: Flow experience, emotional states, self-efficacy and life satisfaction factor analysis results

\begin{tabular}{|l|l|l|l|l|}
\hline Items & Load* & Eigenvalue & $\begin{array}{l}\text { Explained } \\
\text { Variance }\end{array}$ & Mean \\
\hline Balance between challenges and skills - 10 Items & $.742-.560$ & 5.972 & 33.180 & 3.92 \\
\hline Absorption in the Activity - 8 items & $.758-.544$ & 4.355 & 24.197 & 3.88 \\
\hline
\end{tabular}

Kaiser-Meyer-Olkin Sample Adequacy: 95\%; Chi-Square for Bartlett's Sphericity Test: 4549.279; sd:153; $<<0.0001 ; \alpha$ Co-efficient for the scale: 939 ; total explained variance: $57.38 \%$

\begin{tabular}{|l|l|l|l|l|l|}
\hline Positive Emotional State - 10 Items & $.811-.711$ & 5.853 & 29.264 & 3.84 & .865 \\
\hline Negative Emotional State - 10 Items & $.803-.562$ & 5.073 & 25.367 & 2.01 & .881 \\
\hline Kai
\end{tabular}

Kaiser-Meyer-Olkin Sample Adequacy: 91 \%; Chi-Square for Bartlett's Sphericity Test: 4501.030; sd:190; p<0.0001; $\alpha$ Co-efficient for the scale: .835; Explained Total variance: $54.63 \%$

\begin{tabular}{|l|l|l|l|l|}
\hline Self-Efficacy - 10 Items & $.781-.662$ & 5.301 & 53.007 & 3.79 \\
\hline
\end{tabular}

Kaiser-Meyer-Olkin Sample Adequacy: 92\%; Chi-Square for Bartlett's Sphericity Test: 2014.974; sd:45; p<0.0001; $\alpha$ Co-efficient for the scale: $53 \%$

\begin{tabular}{|l|l|l|l|l|}
\hline Life Satisfaction- 4 Items & $.882-.803$ & 2.891 & 72.267 & 3.22 \\
\hline $\begin{array}{l}\text { Kaiser-Meyer-Olkin Sample Adequacy:82\%; Chi-Square for Bartlett's Sphericity Test: 853.919; sd:6; p<0.0001; Explained Total variance; } \\
72 \%\end{array}$
\end{tabular}
$72 \%$

*The largest and smallest factor of the items is the load ranges. Source: Authors

2012, p. 219). KMO value is expected to be higher than 0.50 and Barlett test results should be significant to evaluate whether the data set is suitable for factor analysis (Hair et al., 2010). Bartlett's spherical test values of KMO and data in Table 2 show that the scales used are suitable for factor analysis. Based on the determined results, it can be said that the structure validity of the flow experience scale adapted to Turkish and other scale structures (It has been determined that the structure/structures to be measured are measured by those items/dimensions) (Erkuş, 2009, p. 135).

Correlation analysis results to determine the relationship between the variables are given in Table 3. The results show that life satisfaction has a significant relationship with self-efficacy $(r=.600$ $\mathrm{p}<.01)$, negative emotion $(\mathrm{r}=-0.093 \mathrm{p}<.01)$, negative emotion $(\mathrm{r}=0.299 \mathrm{p}<.01)$, absorption in the activity $(r=0.392 \mathrm{p}<.01)$, balance between challenges and skills $(r=.401 \mathrm{p}<.01)$. There is a positive significant correlation between negative mood of self-efficacy $(r=-0.170 \mathrm{p}<.01)$, positive $\operatorname{mood}(\mathrm{r}=.388 \mathrm{p}<.01)$, absorption in the activity $(r=.501 \mathrm{p}<.01)$, the balance between challenges and skills $(r=.541$ $\mathrm{p}<.01)$. In addition, the results show that there is a positive correlation between positive mood and the balance between challenges and skills $(r=.388$ $\mathrm{p}<.01)$ and absorption in the activity $(\mathrm{r}=.435 \mathrm{p}<.01)$ and a negative correlation between negative mood and the balance between challenges and skills $(r=-$ $.266 \mathrm{p}<.01)$ and absorption in the activity $(\mathrm{r}=-.179$ $\mathrm{p}<.01)$. A significant negative correlation was found between positive $\operatorname{mood}(r=-.184 \mathrm{p}<.01)$ and negative mood. Finally, there seems to be a positive linear and high correlation between balance between challenges and skills and absorption in activity $(r=.746 \mathrm{p}<.01)$. It is undesirable to have a coefficient of .90 and above for the expressions that are tested to be related to each other (Hair et al., 2010). Therefore, it can be said that these two subscales, which are not independent from each other, do not have the same meaning.

Table 3: Table of correlation values between variables

\begin{tabular}{|c|c|c|c|c|c|c|c|c|}
\hline & & 1 & 2 & 3 & 4 & 5 & 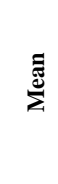 & 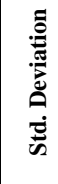 \\
\hline 1 & $\begin{array}{l}\text { Balance between } \\
\text { Challenges and } \\
\text { Skills }\end{array}$ & & & & & & 3.91 & .77 \\
\hline 2 & $\begin{array}{l}\text { Absorption in the } \\
\text { Activity }\end{array}$ & $.746^{* *}$ & & & & & 3.93 & .77 \\
\hline 3 & $\begin{array}{l}\text { Positive Emotional } \\
\text { State }\end{array}$ & $.388^{* *}$ & $.435^{* *}$ & & & & 3.84 & .80 \\
\hline 4 & $\begin{array}{l}\text { Negative } \\
\text { Emotional State }\end{array}$ & $-.266^{* *}$ & $-.179^{* *}$ & $-.184^{* *}$ & & & 2.01 & .95 \\
\hline 5 & Self-Efficacy & $.541^{* *}$ & $.501^{* *}$ & $.388^{* *}$ & $-.170^{* * *}$ & & 3.78 & .71 \\
\hline 6 & Life Satisfaction & $.401^{* *}$ & $.392^{* *}$ & $.299^{* *}$ & $-.093^{* * *}$ & $.600^{* *}$ & 3.22 & .92 \\
\hline
\end{tabular}

Source: Authors

Regression analysis was applied to test the research hypotheses. Multiple regression analysis results performed to determine the effect of flow experience and emotions on self-efficacy are summarized in Table 4. 
Journal of multidisciplinary academic tourism 2021, 6 (2): 127-142

Table 4: Regression analysis results regarding the effect of flow experience and emotion on self-efficacy

\begin{tabular}{|c|c|c|c|c|c|c|c|c|}
\hline \multirow[t]{2}{*}{ Model } & \multicolumn{2}{|c|}{$\begin{array}{l}\text { Non-standardized } \\
\text { coefficients }\end{array}$} & \multirow{2}{*}{\begin{tabular}{|l}
$\begin{array}{l}\text { Standardized co- } \\
\text { efficient }\end{array}$ \\
Beta
\end{tabular}} & \multirow[t]{2}{*}{ t-value } & \multirow{2}{*}{$\begin{array}{l}\text { Meaning } \\
\text { level }\end{array}$} & \multicolumn{3}{|c|}{ Related Statistics } \\
\hline & B & Std. Error & & & & Tolerance & VIF & CI \\
\hline (Constant) & 1.332 & .204 & & 6.532 & .000 & & & 1.000 \\
\hline $\begin{array}{l}\text { Balance between Challenge } \\
\text { and Skills }\end{array}$ & $\mathbf{s} .323$ & .056 & .347 & 5.752 & .000 & .422 & 2.368 & 5.087 \\
\hline Absorption in the Activity & .149 & .056 & .161 & 2.652 & .008 & .417 & 2.396 & 13.029 \\
\hline Positive Emotion & .162 & .039 & .181 & 4.110 & .000 & .794 & 1.260 & 17.583 \\
\hline Negative Emotion & -.012 & .031 & -.016 & -.381 & .703 & .919 & 1.089 & 22.856 \\
\hline $\begin{array}{l}\text { Dependent Variable: Self-Effica } \\
\text { DW: } 1.838\end{array}$ & & Model: $\mathrm{R}=$ & $.584 ; \mathrm{R}^{2}=0.341$ & Adjusted & ${ }^{2}=0.335 ; \mathrm{F}$ & $55.524, \mathrm{p}<0$ & 001 & \\
\hline
\end{tabular}

Source: Authors

According to the model, $33.5 \%$ of the total variance related to the dependent variable (self-efficacy) is explained by independent variables (flow experience and emotional state). (F: 55.524 $\mathrm{p}<0.0001$ ). The constant term was found to be 1.332. This means that even if the independent variable is zero, 1.332 unit of value is obtained for self-efficacy.

One unit increase in balance between challenges and skills increases self-efficacy by .323 units, while one unit increase in absorption in the activity increases self-efficacy by .149 units. However, one unit increase in positive emotion increases selfefficacy .162 units. Based on these results, H1a, $\mathrm{H} 1 \mathrm{~b}$ and $\mathrm{H} 2 \mathrm{a}$ hypotheses were accepted. Since the negative emotion did not have a significant effect on self-efficacy $(\mathrm{t}=-$. $381 ; \mathrm{p}>0.05)$, the $\mathrm{H} 2 \mathrm{~b}$ hypothesis was rejected.

When Table 5 is examined, the model was found significant (F: $47.351 \mathrm{p}<0.0001$ ). $18.9 \%$ of the total variance related to the dependent variable, ie life satisfaction, is explained by the flow experience subscales and emotional states. The constant term was found to be .709. This means that even if the arguments are zero, .709 units of value are obtained for life satisfaction. One-unit increase in balance between challenges and skills increases life satisfaction by .277 units, while one-unit increase in adopting activity increases life satisfaction by .191 units. However, one-unit increase in positive emotions increase life satisfaction by .165 unit.

According to the model, only negative emotions did not have statistically significant correlation life satisfaction. Three of the independent variables are statistically significant in affecting life satisfaction.

Based on this result, 'balance between challenges and skills' ( $\mathrm{t}: 3.478 ; \mathrm{p}<0.000)$, 'absorption in the activity' ( $\mathrm{t}: 2.398 ; \mathrm{p}<0.000)$ and 'positive emotions' $(\mathrm{t}: 2.964 ; \mathrm{p}<0.000)$ may have an impact on the life

Table 5: Regression equality test for flow experience and emotional situations satisfaction

\begin{tabular}{|c|c|c|c|c|c|c|c|c|}
\hline \multirow[t]{2}{*}{ Model } & \multicolumn{2}{|c|}{$\begin{array}{l}\text { Non-standardized } \\
\text { coefficients }\end{array}$} & \multirow{2}{*}{\begin{tabular}{|l}
$\begin{array}{l}\text { Standardised co- } \\
\text { efficient }\end{array}$ \\
Beta
\end{tabular}} & \multirow{2}{*}{ t-value } & \multirow{2}{*}{$\begin{array}{l}\text { Meaning } \\
\text { Level }\end{array}$} & \multicolumn{3}{|c|}{ Related Statistics } \\
\hline & B & Std. Error & & & & Tolerance & VIF & CI \\
\hline (Constant) & .709 & .289 & & 2.454 & .015 & & & 1.000 \\
\hline $\begin{array}{l}\text { Balance between challenges and } \\
\text { skills }\end{array}$ & 277 & .080 & .232 & 3.478 & .001 & 422 & 2.368 & 5.067 \\
\hline Absorption in Activity & .191 & .080 & .161 & 2.398 & .017 & 417 & 2.396 & 13.029 \\
\hline Positive Emotional State & .165 & .056 & .144 & 2.964 & .003 & .794 & 1.260 & 17.583 \\
\hline Negative Emotional State & .023 & .044 & .023 & .519 & .604 & .919 & 1.089 & 22.856 \\
\hline $\begin{array}{l}\text { Dependent variable: Life Satisfact } \\
\text { DW: } 1.725\end{array}$ & & Model: $\mathrm{R}=$ & $443 ; \mathrm{R}^{2}=0.197 ; A$ & Adjusted & $=0.189 ; \mathrm{F}=$ & $5.259, \mathrm{p}<0.0$ & & \\
\hline
\end{tabular}

Source: Authors 
satisfaction of the participants. According to Table 5, H3a, H3b and H4a hypotheses are supported. $\mathrm{H} 4 \mathrm{~b}$ is not supported.

Variance Inflation Factor (VIF) and DurbinWatson (DW) statistics are two approaches to test the explanatory variables and they should not be multiple linear dependent and sequential dependent in the regression model. VIF tests for multiple linear dependencies between the explanatory variables and if VIF $=1$ indicates that multiple linear dependencies disappear and 1 $<\mathrm{VIF} \leq 5$ indicates moderate multiple linear dependencies (Özdamar, 2011, p. 526). The DurbinWatson coefficient is used to test autocorrelation (whether the error terms show consecutive dependency) and the DW value is expected to be between 1.5 and 2.5 (Kalayc1, 2010). DW values (1.838- 1.725$)$ ranging from 1.5 to 2.5 indicate no autocorrelation. DW values (1.838- 1.725) ranging from 1.5 to 2.5 indicate no autocorrelation. Other coefficients to be considered are the tolerance value $(\mathrm{TV}=$ Tolerance Value $=1-\mathrm{R} 2)$ and the condition index (CI = Condition Index). The tolerance value indicates whether there is a connection problem like VIF value and if it is greater than .10, it indicates that there is no multiple connection problem between variables (Sipahi et al., 2010, p. 170; Cokluk et al., 2012, p. 36). According to the models in Table 4 and Table 5, there is no multiple connection problem, since the tolerance value between each variable and self-efficacy and life satisfaction is in the range of .417- .919. In the condition index, it is an indication of whether there is a multiple c onnection problem. In addition, if the CI value is between 10 and 30 , then it is at the "medium level", and if it is greater than 30, then it indicates "high level" multiple linear connection problem (Çokluk et al., 2012, p. 36).

According to both models, the balance between challenges and skills and self-efficacy (5.087) and life satisfaction (5.067) do not show multiple direct connectivity problems. In addition, it can be said that the multiple connection problem is at a medium level since there is a condition index value (in the range of $13.029-22.856$ ) between the variables and self-efficacy and life satisfaction.

When Table 6 is examined, the model created was found significant ( $\mathrm{F}: 51.162 \mathrm{p}<0.0001)$. According to the model, $35.8 \%$ of the total variance related to the dependent variable (life satisfaction) is explained by self-efficacy (Büyüköztürk, 2013, p. 98). The constant term was found to be 0.316 . This means that even if the independent variable is zero, a value of 0.316 is obtained for life satisfaction. An increase in self-efficacy increases life satisfaction by 0.769 units.

Considering the model found significant, selfefficacy is statistically significant in influencing life satisfaction. Based on this result, it can be said that self-efficacy ( $\mathrm{t}: 15.571 ; \mathrm{p}<0.000)$ has a positive effect on life satisfaction. H5 hypothesis is supported for the model according to Table 6 .

Considering the VIF value according to the findings in Table 6, there is no multiple linear dependence between self-efficacy and life satisfaction $(\mathrm{VIF}=1)$. The $\mathrm{DW}$ value (1.765) ranging from 1.5 to 2.5 indicates no autocorrelation. Considering the tolerance value $(\mathrm{TV}=1.000)$ between self-efficacy and life satisfaction, there is no multiple connection problem. The condition index (CI) suggests that the multiple connection problem between self-efficacy and life satisfaction (10.615) is at a medium level.

\section{Conclusion}

This study has been carried out on individuals participating in recreational activities (being active in indoor and outdoor areas) and aims to understand the reasons why individuals participate in activities. The research is based on the Social Cognitive Theory, which is related to Flow Theory and behaviors. We identified the role of the flow experiences, positive and negative emotions of individuals performing recreative activities on self-efficacy. In addition, we also looked in to the effects of flow experiences, positive

Table 6: Regression equality test regarding self-efficacy and life satisfaction

\begin{tabular}{|c|c|c|c|c|c|c|c|c|}
\hline \multirow[t]{2}{*}{ Model } & \multicolumn{2}{|c|}{$\begin{array}{c}\text { Non-standardised co- } \\
\text { efficient }\end{array}$} & \multirow{2}{*}{\begin{tabular}{|c}
$\begin{array}{c}\text { Standardised } \\
\text { co-efficient }\end{array}$ \\
Beta
\end{tabular}} & \multirow{2}{*}{ t-value } & \multirow{2}{*}{$\begin{array}{l}\text { Meaning } \\
\text { Level }\end{array}$} & \multicolumn{3}{|c|}{ Related Statistics } \\
\hline & B & Std. Error & & & & \begin{tabular}{|l|} 
Tolerance \\
\end{tabular} & VIF & $\overline{\mathrm{CI}}$ \\
\hline (Constant) & .316 & .190 & & 1.664 & .097 & & & 1.000 \\
\hline Self- Efficacy & .769 & .049 & .600 & 15.571 & .000 & 1.000 & 1.000 & 10.615 \\
\hline \multicolumn{2}{|c|}{$\begin{array}{l}\text { Dependent Variable: Life Satisfaction } \\
\text { DW: } 1.765\end{array}$} & \multicolumn{7}{|c|}{ Model: $\mathrm{R}=0.600 ; \mathrm{R}^{2}=0.359 ;$ Adjusted $\mathrm{R}^{2}=0.358 ; \mathrm{F}=51.162, \mathrm{p}<0.0001$} \\
\hline
\end{tabular}


and negative emotions and self-efficacy on life satisfaction. The research is focused on the relationship structure of each variable and compared the purpose of the research through the relevant analysis.

Firstly, the participants who are active in open and closed areas were described. Based on the findings, data varies considerably in terms of different cities, and indoor and outdoor activities. The results of are more generalizable for individuals engaged in recreational activities. In the next stage, research hypotheses were tested. In this process, the balance between the challenges and skills that constitute the subscale of the flow experience of individuals participating in recreation activities was expected to positively affect the self-efficacy. The findings supported this expectation. In other words, findings show that the balance between challenges and skills leads to an increase in selfefficacy.

This result shows that the individual who undertakes the activity knows what to do, feels that the activity and his/her skills are compatible and can meet the requirements of the event. The individual also believes that he/she can cope with the difficulties. At the same time, absorption in the activity, not understanding how time passes and being completely immersed in the activity increases the belief that the individual can transform the skills into action. Theoretically, the research echoes similar results with the work of Hong et al. (2012), Mesurado et al. (2016) and Tandon (2017). In addition, the findings are in line with Reid's (2004) study which determined that the feeling of control, one of the general abilities of the flow experience, increased self-efficacy. Therefore, in this study, the balance between challenges and skills, including the sense of control, and absorption in the activity affects self-efficacy.

Secondly, during the process of testing hypotheses, it was expected that individual's self-efficacy and negative emotional states would negatively affect their self-efficacy. Based on the results of the analysis, only positive emotions support this expectation. It was determined that the effect of negative emotions on self-efficacy was insignificant. In other words, although the positive emotions caused an increase in self-efficacy, negative emotions did not affect self-efficacy as expected. This result shows individual who joins recreational activities believes that the emotional, strong, enthusiastic, proud, vigilant, inspired, determined, careful and active moods are sufficient. On the other hand, negative emotional states such as being troubled, sad, nervous, anxious, did not affect the self-efficacy belief. Yalnız's research (2014) with university students supports the findings regarding the positive effect of positive emotional state on self-efficacy. His study revealed that the positive emotions of the students had a positive effect on their self-efficacy, while their negative affect had a negative effect on their self-efficacy. However, the results contradict the study in terms of negative emotional states. Unlike this study, his research was directly student-oriented and this may be the reason for this contradiction.

Thirdly, it was expected that balance between challenges and skills and the absorption in activity would positively affect the life satisfaction. The findings obtained support this expectation. This result shows that the individuals who fulfill the activity know what to do during the event, feel that the activity and skills are compatible and that they can meet the requirements of the event, and believe that they can cope with the difficulties. When the related literature is examined, the results of Peterson, Park and Seligman (2005), Chen et al. (2010) and Ayazlar (2015) are in line with the results of this research.

Fourth, in testing hypotheses, it was expected that positive emotional states of the individuals would affect their life satisfaction positively whereas their negative emotional states would negatively affect their life satisfaction. The results of the analysis show that positive emotions increase life sense, while negative emotions do not significantly affect life satisfaction. Negative emotions did not support this expectation and its effect on life satisfaction was found insignificant. In other words, the findings show that although the positive emotions cause an increase in life satisfaction, and the negative emotion do not decrease life satisfaction. This result shows that if the active individual has an excited, strong, enthusiastic, proud, alert, inspired, determined, careful and active emotional state, this will contribute to the life satisfaction. On the other hand, this finding indicates that when the individual has negative feelings such as distressed, sad, nervous, anxious, this situation does not affect life satisfaction positively or negatively. From a theoretical point of view, the positive effect of positive emotions on life satisfaction align with the research of Deniz et al. (2012) and Kuppens et al. (2008).

Fifth, self-efficacy of individuals was expected to positively affect their life satisfaction. The findings support this expectation. In other words, findings 
show that self-efficacy increases life satisfaction. From a theoretical point of view, the studies of Sahranç (2008), Telef (2011), Çakar (2012) and Capri et al. (2012) examine the relationship between self-efficacy and life satisfaction and support the findings of this research.

Based on the relevant findings and inferences, some suggestions have been developed for the enterprise or operators. Within the scope of the flow experience, balance between challenges and skills can be taken into account by the companies that work with intensive business timetable (for example: businesses where the service is offered on site, such as hotels, restaurants). As the flow experience will increase the belief that the individual will be able to fulfill one's duties in the business life, the performance will also increase. This can be achieved by stripping the working individual from the busy work schedule for a while and encouraging participation in recreational activities. It may even play a greater role in the belief that the individual performing the activity will be more prone to positive emotions. On the other hand, activities should be carried out to increase the self-efficacy beliefs of individuals who perform the activity. For example, the individual's successful performances in the past may have increased self-efficacy (Bandura, 1977). When the individual has successful experiences, there is an increase in self-efficacy. Or the individual's active, enthusiastic and exciting emotional situations (Bandura, 1977) while performing the activity contribute to self-efficacy. This causes an increase in any action performance. In this regard, businesses can increase the life satisfaction of the employee with a self-efficacy belief. A productive, happy employee with life-satisfaction can be provided with different experiences. For example, organizing a sports organization such as football or basketball once a week, or organizing a regular course can be helpful for increasing the self-efficacy of employees.

A further suggestion can be made for managers of sports clubs, fitness centre operators, course managers (such as swimming, dancing) and public managers. More individuals should be directed to do physical activities for themselves, regardless of whether they are indoor or outdoor activity. If necessary, they should take an initiative together (such as public awareness or raising awareness with collective organizations). It is necessary to ensure that individuals use their abilities and skills to ensure that they develop positive emotions. From a social perspective, training of individuals who are trying to develop a healthier and conscious self-development has paramount importance because these are the basic needs for individuals in life (Özer \& Topaloğlu, 2008). Therefore, self-realization is an ever-ending need of the individual.

Lastly, the study has a number of limitations. The variables (flow experience, positive and negative emotional states, self-efficacy and life satisfaction) used in the research make up the structural limitation of this study. There are some restrictions on the data collection process of the research. Due to the financial limitations, research data were collected from Mersin and nearby provinces.

\section{References}

Akgündüz, Y. (2013). Analysis of relationship between job satisfaction, life satisfaction, and self-efficacy in hospitality business. Manisa Celal Bayar University Journal of Social Sciences, 11(01), 180204.

Aşçı, F. H., Çağlar, E., Eklund, R. C., Altıntaş, A., \& Jackson, S. (2007). The adaptation study of Dispositional Flow Scale-2 and Flow State Scale2. Hacettepe Journal of Sport Sciences, 18(4), 182196.

Ayazlar, R. A. (2015). The effect of flow experience on experience satisfaction and life satisfaction in paragliding (Unpublished doctoral dissertation). Adnan Menderes University, Aydın.

Ayazlar, R. A., \& Yüksel, A. (2018). Flow experience in paragliding: Effects on experience and life satisfaction. Tourism Analysis, 23(4), 461-473. https://doi.org/10.3727/108354218X15391984820 396

Aykol, B., \& Aksatan, M. (2013). A conceptual model and research propositions on the applicability of the flow theory to museum visits. Journal of Marketing and Marketing Research, 12, 69-90.

Aysan, F., \& Bozkurt, N. (2004, July). Life satisfaction, coping strategies with negative automatic thoughts of the school counsellors: Sample of Izmir province. XIII. National Educational Sciences Congress (pp. 6-9). Inönü University, Malatya.

Azar, I. A. S., Vasudeva, P., \& Abdollahi, A. (2006). Relationship between Quality of Life, Hardiness, Self-efficacy and Self-esteem amongst Employed and Unemployed Married Women in Zabol. Iranian Journal of Psychiatry, 1, 104-111.

Baek, Y. M. (2017). The moderating effects of flow on the relationship between stress and satisfaction with life, university life satisfaction. Journal of the Korea Academia-Industrial Coperation Society, 18(5), 490-496. https://doi.org/10.5762/KAIS.2017.18.5.490 
Bandura, A. (1977). Self-efficacy: Toward an unifying theory of behavioral change. Psychological Review, 84, 191-215. https://doi.org/10.1037/0033295X.84.2.191

Bandura, A. (1982). Self-Efficacy mechanism in human agency. Amercian Psycholgist. 37(2), 122-147.

Bandura, A. (1986). Social foundations of thought and action: A Social cognitive theory. NJ: PrenticeHall.

Bandura, A. (1994). Self-efficacy. In V. S. Ramachaudran (Ed.), Encyclopedia of human behavior (Vol. 4, pp. 71-81). New York, NY: Academic Press.

Bandura, A., Caprara, G. V., Barbaranelli, C., Pastorelli, C., \& Regalia, C. (2001). Sociocognitive selfregulatory mechanisms governing transgressive behavior. Journal of Personality and Social Psychology, 80(1), 125. https://doi.org/10.1037/0022-3514.80.1.125

Basom, M. R., \& Frase, L. (2004). Creating optimal work environments: Exploring teacher flow experiences. Mentoring \& Tutoring: Partnership in Learning, 12(2), 241-258. https://doi.org/10.1080/1361126042000239965

Bryce, J., \& Haworth, J. (2002). Wellbeing and flow in sample of male and female office workers. Leisure Studies, 21(3-4), 249-263. https://doi.org/10.1080/0261436021000030687

Büyüköztürk, Ş. (2013). Sosyal bilimler için veri analizi el kitabı. Ankara: Pegem Akademi.

Çakar, F. S. (2012). The Relationship between the SelfEfficacy and Life Satisfaction of Young Adults. International Education Studies, 5(6), 123-130. https://doi.org/10.5539/ies.v5n6p123

Caprara, G. V., Steca, P., Gerbino, M., Paciello, M., \& Vecchio, G. M. (2006). Looking for adolescents' well-being: Self-efficacy beliefs as determinants of positive thinking and happiness. Epidemiology and Psychiatric Sciences, 15(1), 30-43. https://doi.org/10.1017/S1121189X00002013

Capri, B., Özkendir, O. M., Özkurt, B., \& Karakuş, F. (2012). General self-efficacy beliefs, life satisfaction and burnout of university students. Procedia-Social and Behavioral Sciences, 47, 968973. https://doi.org/10.1016/j.sbspro.2012.06.765

Certel, Y. D. D. Z., Bahadır, Z., Saracaloğlu, A. S., \& Varol, S. R. (2015). The investigation of the relation between the high school students' self efficacy and subjective well-being. Journal of Research in Education and Teaching, 4(2), 307318.

Çetinkaya, E. (2011). Social support and self-efficacy as the predictors of life satisfaction of retired people (Unpublished master's thesis). Hacettepe University, Ankara.
Chen, L. H., Ye, Y. C., Chen, M. Y., \& Tung, I. W. (2010). Alegría! Flow in leisure and life satisfaction: The mediating role of event satisfaction using data from an acrobatics show. Social Indicators Research, 99(2), 301-313. https://doi.org/10.1007/s11205-010-9581-z

Çokluk, Ö., Şekercioğlu, G., \& Büyüköztürk, Ş. (2012). Sosyal Bilimler Íçin Cok Deŏiskenli Istattistik SPSS \& LISREL Uygulamaları. Ankara: Pegem Akademi.

Collins, A. L., Sarkisian, N., \& Winner, E. (2009). Flow and happiness in later life: An investigation into the role of daily and weekly flow experiences. Journal of Happiness Studies, 10(6), 703-719. https://doi.org/10.1007/s10902-008-9116-3

Cropanzano, R., Weiss, H. M., Hale, J. M., \& Reb, J. (2003). The structure of affect: Reconsidering the relationship between negative and positive affectivity. Journal of management, 29(6), 831857. 2063_03_00081-3

Csikszentmihalyi, M. (1990). The psychology of optimal experience. New York, NY: Harper\&Row.

Csikszentmihalyi, M. (2005). Flow happiness science. (S. K. Akbaş, Trans.). Ankara: HYB Publishing.

Csikszentmihalyi, M., \& LeFevre, J. (1989). Optimal experience in work and leisure. Journal of Personality and Social Psychology, 56(5), 815-822. https://doi.org/10.1037/0022-3514.56.5.815

Dağll, A., \& Baysal, N. (2016). Adaptation of the satisfaction with life scale into Turkish: The study of validity and reliability. Electronic Journal of Social Sciences, 15(59), 1250-1262. https://doi.org/10.17755/esosder.263229

Deniz, M. (2006). The relationships among coping with stress, life satisfaction, decision-making styles and decision self-esteem: An investigation with Turkish university students. Social Behaviour and Personality: An International Journal, 34(9), 1161-1170.

Deniz, M. E., Arslan, C., Özyeşil, Z., \& İzmirli, M. (2012). Self compassion, life satisfaction, negative and positive affect: A comparison between turkey and other different countries' university students. Mehmet Akif Ersoy University Journal of Education Faculty, 33, 424-446.

Diener, E., \& Emmons, R. A. (1984). The independence of positive and negative affect. Journal of Personality and Social Psychology, 47(5), 11051117. https://doi.org/10.1037/0022-3514.47.5.1105

Diener, E., \& Seligman, M. E. (2004). Beyond money: Toward an economy of well-being. Psychological Science in the Public Interest, 5(1), 131. https://doi.org/10.1007/978-90-481-2350-6_9 
Diener, E., Emmons, R. A., Larsen, R. J., \& Griffin, S. (1985). The satisfaction with life scale. Journal of Personality Assessment, 49(1), 71-75. https://doi.org/10.1207/s15327752jpa4901_13

Doğan, Y., \& Özdevecioğlu, M. (2009). The effect of positive and negative emotionality on the performance of employees. The Journal of Social Economic Research, 1(18), 165-190.

Ehrhardt, J. J., Saris, W. E., \& Veenhoven, R. (2000). Stability of life-satisfaction over time. Journal of Happiness Studies, 1(2), 177-205. https://doi.org/10.1023/A:1010084410679

Erkuş, A. (2009). Davranış bilimleri için bilimsel araştırma süreçleri. Ankara: Seçkin Yayın Evi.

Frase, L. E. (1998). An examination of teachers' flow experiences, efficacy, and instructional leadership in large inner-city and urban school districts. Annual Meeting of the American Educational Research Association, 2-33.

Frish, M. B. (2006). Quality of life therapy: Applying a life satisfaction approach to positive psychology and cognitive therapy. New Jersey: John Wiley \& Sons.

Gençöz, T. (2000). Positive and Negative Affect Schedule: A study of validity and reliability. Turkish Journal of Psychology, 15(46), 19-26.

Gupta, G., \& Kumar, S. (2010). Mental health in relation to emotional intelligence and self efficacy among college students. Journal of the Indian Academy of Applied Psychology, 36(1), 61-67.

Hair, J. F., Black, W. C., Babin, B. J., \& Anderson, R. E. (2010). Multivariate Data Analysis (7th ed.). NJ Prentice Hall.

Han, S. (1988). The relationship between life satisfaction and flow in elderly Korean immigrants. In Csikszentmihalyi, M. \& Csikszentmihalyi, I. (Eds), Optimal experience, (pp. 138-149). United Kingdom: Cambridge University Press.

Hong, J. C., Pei-Yu, C., Shih, H. F., Lin, P. S., \& Hong, J. C. (2012). Computer Self-Efficacy, Competitive Anxiety and Flow State: Escaping from Firing Online Game. Turkish Online Journal of Educational Technology-TOJET, 11(3), 70-76.

Jackson, S. A., \& Csikszentmihalyi, M. (1999). Flow in sports. USA: Human Kinetics.

Jackson, S. A., \& Eklund, R. C. (2002). Assessing flow in physical activity: The flow state scale-2 and dispositional flow scale-2. Journal of Sport and Exercise Psychology, 24, 133-150. https://doi.org/10.1123/jsep.24.2.133

Jackson, S. A., \& Marsh, H. W. (1996). Development and validation of a scale to measure optimal experience: The Flow State Scale. Journal of
Sport and Exercise Psychology, 18, 17-35. https://doi.org/10.1123/jsep.18.1.17

Jackson, S. A., Martin, A. J., \& Eklund, R. C. (2008). Long and short measures of flow: The construct validity of the FSS-2, DFS-2, and new brief counterparts. Journal of Sport and Exercise Psychology, 30(5), 561-587. https://doi.org/10.1123/jsep.30.5.561

Kalaycı, Ş. (2010). SPSS uygulamalı çok değişkenli istatistik teknikleri. Anakara: Asil Yayın Dağıtım.

Karasar, N. (2002). Bilimsel araştırma yöntemi. Ankara: Nobel Yayın Evi.

Keskin, E. (2020). Relationships among Self-efficacy, Job Resourcefulness and Job Performance of Hotel Cooks in Cappadocia. Journal of Multidisciplinary Academic Tourism, 5 (1), 17-27 . DOI: 10.31822/jomat.691475

Kızanlıklı, M. M., \& Silik, C. E. (2019). Examination of the self-efficacy of undergraduate students in tourismeducation in terms of academic achievement and individual characteristics. Afyon Kocatepe University Journal of Social Sciences, 21(1), 269-286. http://doi.org/10.32709/akusosbil.484767

Köker, S. (1991). Comparison of normal and problematic adolescents' life satisfaction level (Unpublished master's thesis). Ankara University, Ankara.

Kuppens, P., Realo, A., \& Diener, E. (2008). The role of positive and negative emotions in life satisfaction judgment across nations. Journal of Personality and Social Psychology, 95(1), 66-75. https://doi.org/10.1037/0022-3514.95.1.66

Larson, R., \& Csikszentmihalyi, M. (1978). Experiential correlates of time alone in adolescence. Journal of Personality, 46(4), https://doi.org/10.1111/j.14676494.1978.tb00191.x

Maddux, J. E. (2002). Self-efficacy: The power of believing you can. In Snyder, C. R. \& Lopez, S. J. (Eds), Handbook of positive psychology (pp. 277287). New York, NY: Oxford University Press.

Magyaródi, T., Nagy, H., Soltész, P., Mózes, T., \& Oláh, A. (2013). Psychometric properties of a newly established flow state questionnaire. The Journal of Happiness \& Well-Being, 1(2), 85-96.

Marat, D. (2003, November). Assessing self-efficacy and agency of secondary school students in a multicultural context: Implications for academic achievement. Proceedings of the New Zealand and Australian Association for Research in Education Conference (pp. 1- 19), Australia.

Mesurado, B., Cristina Richaud, M., \& José Mateo, N. (2016). Engagement, flow, self-efficacy, and Eustress of University Students: a cross-national 
comparison between the Philippines and Argentina. The Journal of psychology, 150(3), 281-299.

https://doi.org/10.1080/00223980.2015.1024595

Moneta, G. B. (2004). The flow experience across cultures. Journal of Happiness Studies, 5(2), 115121.

https://doi.org/10.1023/b:johs.0000035913.65762. b5

Nakamura, J., \& Csikszentmihalyi, M. (2002). The concept of flow. In C. R. Snyder \& S. J. Lopez (Eds.), Handbook of positive psychology (pp. 89105). New York, NY, US: Oxford University Press.

Neugarten, B. L., Havighurst, R. J., \& Tobin, S. S. (1961). The measurement of life satisfaction. Journal of Gerontology, 16, 134-143.

Nunnally, J. C. (1978). Psychometric Theory (2nd ed.) New York, NY: McGraw-Hill.

Özdamar, K. (2011). Paket programlar ile istatistiksel veri analizi. İstanbul: Kaan Kitapevi.

Özdemir, A. S., Durhan, T. A., \& Akgül, B. (2020). Validity and reliability study of adapting flow life scale to recreational activites. Gazi Journal of Physical Education and Sport Sciences, 25(2), 107-116.

Özer, P., \& Topaloğlu, T. (2008). Leadership and motivation-scope theories in motivation. Ankara: Nobel Publishing.

Palmer, B., Donaldson, C., \& Stough, C. (2002) Emotional intelligence and life satisfaction. Personality and Individual Differences, 33(7), 1091-1100. https://doi.org/10.1016/s0191-8869(01)00215-x

Peterson, C., Park, N., \& Seligman, M. E. (2005). Orientations to happiness and life satisfaction: The full life versus the empty life. Journal of happiness studies, 6(1), 25-41. https://doi.org/10.1007/s10902-004-1278-z

Reid, D. (2004). The influence of virtual reality on playfulness in children with cerebral palsy: A pilot study. Occupational Therapy International, 11(3), $131-144$ https://doi.org/10.1002/oti.202

Rheinberg, F., Vollmeyer, R., \& Engeser, S. (2003). Die erfassung des flow-erlebens [The assessment of flow experience]. In J. Stiensmeier-Pelster \& F. Rheinberg (Eds.), Diagnostik von Selbstkonzept, Lernmotivation und Selbstregulation [Diagnosis of motivation and self-concept] (pp. 261-279). Go"ttingen: Hogrefe.

Şahan, H., Tekin, M., Yıldız, M., Eraslan, M., Yıldız, M., Sim, H., \& Yarar, N. D. (2012). Examination of self-efficacy and life satisfaction levels of students receiving education in schools of physical education and sports. World Academy of Science,
Engineering and Technology, 66, 942-944. doi.org/10.5281/zenodo.1329655

Sahranç, Ü. (2007). A flow model related to stress control appraisal, general self-efficacy, state anxiety and life satisfaction (Unpublished doctoral dissertation). Gazi University, Ankara.

Sahranç, Ü. (2008). A state flow model: The relationships among stress control, general self-efficacy, state anxiety, life satisfaction and state flow. Sakarya University Journal of Education Faculty, 16, 122144.

Schwarzer, R., Bäßler, J., Kwiatek, P., Schröder, K., \& Zhang, J. X. (1997). The assessment of optimistic self-beliefs: comparison of the German, Spanish, and Chinese versions of the general self-efficacy scale. Applied Psychology, 46(1), 69-88. https://doi.org/10.1111/j.14640597.1997.tb01096.x

Sekaran, U. (1992). Research methods for business: a skill building approach. John Wiley \& Sons.

Sidorová, D. (2015). Well-being, flow experience and personal characteristics of individuals who do extreme sports as serious leisure. (Unpublished Doctoral Thesis). Masaryk University. Brno, Czech Republic. Czechia.

Singh, B., \& Udainiya, R. (2009). Self-efficacy and wellbeing of adolescents. Journal of the Indian Academy of Applied Psychology, 35(2), 227-232.

Sipahi, B., Yurtkoru, S., \& Cinko, M. (2010). Sosyal bilimlerde SPSS'le veri analizi. İstanbul: Beta Yayınları

Tandon, T. (2017). A Study on relationship between self efficacy and flow at work among young adults. The International Journal of Indian Psychology, 4(4), 87-100.

Telef, B. B. (2011). The study of teachers' self-efficacy, job satisfaction, life satisfaction and burnout. Elementary Education Online, 10(1), 91108.

Tipton, R. M., \& Worthington, E. L. (1984). The measurement of generalized self-efficacy: A study of construct validity. Journal of personality assessment, 48(5), 545548. https://doi.org/10.1207/s15327752jpa4805_1 4

TÜİK. (2018). Türkiye İstatistik Kurumu, http://www.tuik.gov.tr (last accessed: 26. 06. 2018).

Turan, N. (2019). A general literature review on flow experience. Pamukkale University Journal of Social Sciences Institute, (37), 181-199. https://doi.org/10.30794/pausbed.562564

Verbruggen, M., \& Sels, L. (2010). Social-cognitive factors affecting clients' career and life 
satisfaction after counseling. Journal of Career Assessment, 18(1),

https://doi.org/10.1177/1069072709340516

Warr, P. B., Barter, J., \& Brownbridge, G. (1983). On the independence of positive and negative affect. Journal of Personality and Psychology, 44(3), 644651. https://doi.org/10.1037/0022-3514.44.3.644

Watson, D., Clark, L. A., \& Tellegen, A. (1988). Development and validation of brief measures of positive and negative affect: the PANAS scales. Journal of personality and social psychology, 54(6), 1063-1070.

Yalnız, A. (2014). Academic self-efficacy: predictive roles of positive and negative affect. Journal of Research in Education and Teaching, 3(2), 95-101.

Yeşilay, A., Schwarzer, R., \& Jerusalem, M. (1996). (2020, February 5). Turkish adaptation of the general perceived self-efficacy scale. Retrieved from http://userpage.fu-berlin.de/ health/turk.htm.

Yetim, Ü. (2001). Toplumdan bireye mutluluk resimleri. İstanbul: Bağlam Yayınları. 


\title{
INFO PAGE \\ How do flow experiences and emotional states of individuals participating in recreational activities affect their self-efficacy perceptions and life satisfaction?
}

\begin{abstract}
This research is based on social cognitive theory and aims to determine the effects of flow experience and positive and negative emotional states of individuals participating in recreational activities on their self- efficacy. The study also aimed to explore the effect of flow experience, self-efficacy, and positive-negative emotions on individuals' life satisfaction. The data were collected through a valid and reliable scale. Convenient sampling method was employed and 434 valid questionnaires were collected between January and April 2018. Hypotheses were tested by multiple regression analysis. Results show the balance between challenges and skills subscale of flow experience and positive emotional state affect self-efficacy. In addition, life satisfaction is affected by by flow experience, positive emotions and self-efficacy. Based on the relevant findings and inferences, some suggestions have been developed for the enterprise or operators. Within the scope of the flow experience, balance between challenges and skills can be taken into account by the companies that work with intensive business timetable (for example: businesses where the service is offered on site, such as hotels, restaurants). A further suggestion can be made for managers of sports clubs, fitness centre operators, course managers (such as swimming, dancing) and public managers. More individuals should be directed to do physical activities for themselves, regardless of whether they are indoor or outdoor activity.
\end{abstract}

Keywords: Flow Experience, Positive Emotions, Negative Emotions, Self-Efficacy, Life Satisfaction

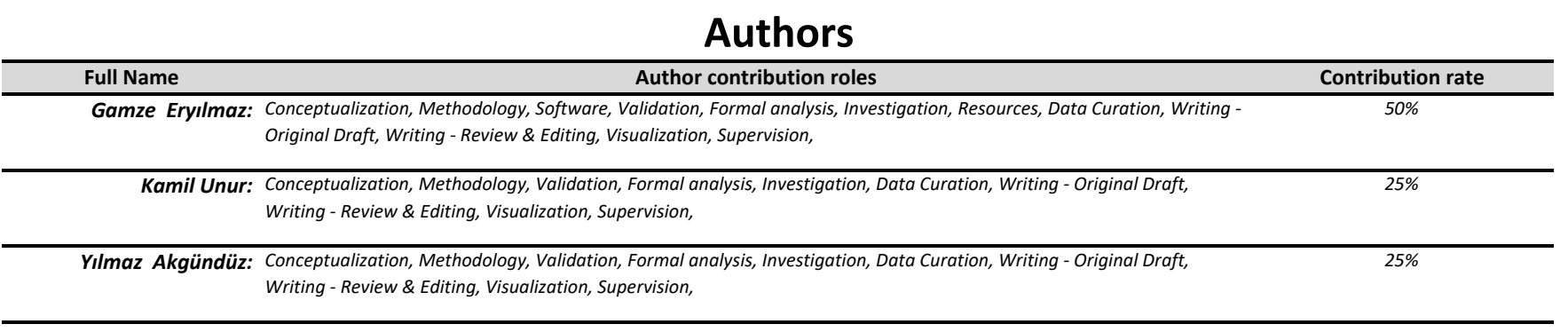

Author statement: Author(s) declare(s) that All procedures performed in studies involving human participants were in accordance with the ethical standards of the institutional and/or national research committee and with the 1964 Helsinki declaration and its later amendments or comparable ethical standards. Declaration of Conflicting Interests: The author(s) declared no potential conflicts of interest with respect to the research, authorship, and/or publication of this article

\author{
This paper does not required ethics committee report \\ Justification: This research was conducted before January 1, 2020. For this reason, it is exempt from "ULAKBIM \\ TRDizin" criterion.
}

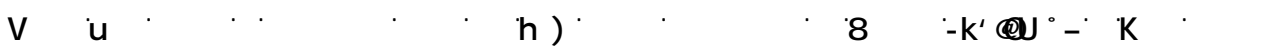

